\title{
Atlantic Cod Trypsin-Catalyzed Peptide Synthesis with Inverse Substrates as Acyl Donor Components
}

\author{
Tomoyoshi Fuchise, ${ }^{a}$ Hideki Kishimura, ${ }^{b}$ Zhi-hong Yang, ${ }^{c}$ Mareshige Kojoma, ${ }^{a}$ Eiko Toyota, ${ }^{a}$ and \\ Haruo SEKIZAKI $*, a$ \\ ${ }^{a}$ Faculty of Pharmaceutical Sciences, Health Sciences University of Hokkaido; Ishikari-Tobetsu, Hokkaido 061-0293, \\ Japan: ${ }^{b}$ Laboratory of Marine Products and Food Science, Research Faculty of Fisheries Sciences, Hokkaido University; \\ Hakodate, Hokkaido 041-8611, Japan: and ${ }^{c}$ Pharmacy Department, Medical College of Qingdao University; Qingdao \\ 266021, Shandong, China. Received November 9, 2009; accepted January 19, 2010; published online January 20, 2010
}

\begin{abstract}
Atlantic cod trypsin-catalyzed peptide synthesis has been studied by using $p$-amidino- and $p$-guanidinophenyl esters of $N$-(tert-butyloxycarbonyl)amino acid as acyl donor components. The reaction temperature was optimized at $0^{\circ} \mathrm{C}$. The method was shown to be successful as effectively for synthesizing the peptide and useful for preparing dipeptide between D-amino acid with D-amino acid and $\beta$-amino acid with $\beta$-amino acid, respectively. The enzymatic hydrolysis of the resulting products was negligible.
\end{abstract}

Key words Atlantic cod trypsin; enzymatic peptide synthesis; inverse substrate; cold-adapted trypsin; $N$-(tert-butyloxycarbonyl)amino acid $p$-amidinophenyl ester; $N$-(tert-butyloxycarbonyl)amino acid $p$-guanidinophenyl ester

A large number of biologically active peptides have been isolated recently from bacterial, fungal, plant and animal sources and characterized in some detail. In particular, shortsequence peptides play important roles in the sensory appreciation of food toward four basic taste sensations (sweet, bitter, sour and salty). ${ }^{1)}$ Such peptides sometimes contain Damino acid and other unusual amino acids. Synthetic chemistry has witnessed remarkable progress with the development of novel biologically active peptides. Enzymatic peptide synthesis has emerged as a powerful approach to the preparation of short sequences. Especially, peptide synthesis using protease-catalyzed reverse reaction has been extensively studied with a variety of amino acids and peptide derivatives as coupling components. ${ }^{2-8)}$ It has been reported that the protease-catalyzed peptide synthesis is superior to the chemical coupling method because it is highly stereoselective, racemization-free, and requires less side-chain protection. The major drawback of the enzymatic method, however, is the respective substrate specificity. Thus, the application of proteases for peptide synthesis has not been fully investigated synthetic possiblity of a number of biologically significant peptides containing D-amino acid or other unusual amino acids. A few previous reports have shown the enzymatic condensation of noncorded amino acids, ${ }^{9,10)}$ peptide mimetics, ${ }^{11)}$ peptide conjugates, ${ }^{12)}$ and D-amino acid. ${ }^{13)}$

Previously, we reported that the inverse substrates such as $p$-amidino- ${ }^{14)}$ and $p$-guanidinophenyl esters ${ }^{15-17)}$ behave as specific substrates for trypsin and trypsin-like enzymes and allow the specific introduction of an acyl group carrying a non-specific residue into the enzymatic active site. The characteristics of inverse substrates suggested that they are useful for enzymatic peptide synthesis. ${ }^{18-24)}$

Many studies on the characterization of trypsins from cold-adapted species have been reported. ${ }^{25)}$ These trypsins display substantially higher catalytic efficiency than their mammalian counterparts. ${ }^{25-33)}$ We previously reported the chum salmon trypsin-catalyzed synthesis of peptides using inverse substrates. ${ }^{23,24)}$ We had obtained commercially available Atlantic cod trypsin at almost the same time. We are interested in comparing of the catalytic efficiency of Atlantic cod trypsin with chum salmon trypsin. In the present work, we investigated Atlantic cod trypsin-catalyzed peptide synthesis using $p$-amidino- and $p$-guanidinophenyl esters of $N^{\alpha}$ tert-butyloxycarbonyl (Boc)-amino acid as acyl donor components with two types of acyl acceptors. We have found that Atlantic cod trypsin-catalyzed peptide synthesis of the Damino acid and $\beta$-amino acid-containing products is more efficient than chum salmon trypsin-catalyzed synthesis.

\section{Results and Discussion}

The kinetic constants for the trypsin-catalyzed hydrolysis of synthetic inverse substrates were analyzed on the basis of the following scheme.

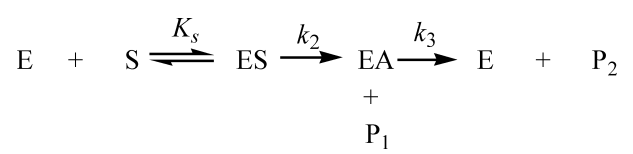

Where: $\mathrm{E}=$ enzyme; $\mathrm{S}=$ substrate; $\mathrm{ES}=$ enzyme-substrate complex; $\mathrm{EA}=$ acyl enzyme; $\mathrm{P}_{1}=$ alcohol component of the substrate; $\mathrm{P}_{2}=$ acid component of the substrate; $K_{s}=$ dissociation constant of enzyme-substrate complex; $k_{2}=$ rate constant of acylation step; and $k_{3}=$ rate constant of deacylation step. The kinetic parameters $K_{s}$ and $k_{2}$ are useful for the evaluation of substrates. The former can provide information on the strength of the bond between the substrate and the enzyme, which is a characteristic of the enzymatic process, while the latter directly reflects the accessibility of the carbonyl function of the substrate molecule to the catalytic residue of the enzyme in the ES complex. The acetic acid and $N^{\alpha}$-Bocamino acid $p$-amidinophenyl esters were subjected to kinetic analysis.

The kinetic parameters were determined as previously described, ${ }^{16)}$ and the values obtained are listed in Table 1 . The parameters were compared with those of chum salmon trypsin. $p$-Amidinophenyl esters behave as specific substrates for Atlantic cod trypsin based on their $k_{2} / K_{s}$ values. The parameter $k_{2} / K_{s}$ has been introduced by Brot and Bender ${ }^{34)}$ to evaluate of the specificity of substrates. The observed $k_{2} / K_{s}$ values for Atlantic cod trypsin, $10^{5}-10^{6}\left(\mathrm{M}^{-1} \mathrm{~s}^{-1}\right)$, are mod- 
Table 1. Kinetic Parameters for the Trypsin-Catalyzed Hydrolysis of Inverse Substrates

$$
\text { Ac-OAm }
$$

\begin{tabular}{lcccc}
\hline \hline \multicolumn{1}{c}{ Enzyme } & $\begin{array}{c}K_{s} \\
(\mathrm{M})\end{array}$ & $\begin{array}{c}k_{2} \\
\left(\mathrm{~s}^{-1}\right)\end{array}$ & $\begin{array}{c}k_{3} \\
\left(\mathrm{~s}^{-1}\right)\end{array}$ & $\begin{array}{c}k_{2} / K_{s} \\
\left(\mathrm{M}^{-1} \mathrm{~s}^{-1}\right)\end{array}$ \\
\hline $\begin{array}{l}\text { Atlantic cod trypsin } \\
\text { Chum salmon trypsin }\end{array}$ & $\begin{array}{c}1.92 \times 10^{-5} \\
3.87 \times 10^{-5}\end{array}$ & $1.35 \times 10$ & $5.66 \times 10^{-3}$ & $7.02 \times 10^{5}$ \\
\hline
\end{tabular}

$$
N^{\alpha} \text {-Boc-L-Ala-OAm (2) }
$$

\begin{tabular}{lcccc}
\hline \hline \multicolumn{1}{c}{ Enzyme } & $\begin{array}{c}K_{s} \\
(\mathrm{M})\end{array}$ & $\begin{array}{c}k_{2} \\
\left(\mathrm{~s}^{-1}\right)\end{array}$ & $\begin{array}{c}k_{3} \\
\left(\mathrm{~s}^{-1}\right)\end{array}$ & $\begin{array}{c}k_{2} / K_{s} \\
\left(\mathrm{M}^{-1} \mathrm{~s}^{-1}\right)\end{array}$ \\
\hline Atlantic cod trypsin & $3.52 \times 10^{-6}$ & $1.93 \times 10$ & 1.39 & $5.49 \times 10^{5}$ \\
Chum salmon trypsin $^{a)}$ & $1.00 \times 10^{-6}$ & $1.28 \times 10$ & 1.14 & $1.28 \times 10^{7}$
\end{tabular}

\begin{tabular}{ccccc}
\hline \multicolumn{2}{c}{$N^{\alpha}$-Boc-D-Ala-OAm (5) } \\
\hline \hline Enzyme & $\begin{array}{c}K_{s} \\
(\mathrm{M})\end{array}$ & $\begin{array}{c}k_{2} \\
\left(\mathrm{~s}^{-1}\right)\end{array}$ & $\begin{array}{c}k_{3} \\
\left(\mathrm{~s}^{-1}\right)\end{array}$ & $\begin{array}{c}k_{2} / K_{s} \\
\left(\mathrm{M}^{-1} \mathrm{~s}^{-1}\right)\end{array}$ \\
\hline $\begin{array}{l}\text { Atlantic cod trypsin } \\
\text { Chum salmon trypsin }\end{array}$ & $\begin{array}{c}8.37 \times 10^{-6} \\
4.00 \times 10^{-6}\end{array}$ & $\begin{array}{c}1.17 \times 10 \\
9.01\end{array}$ & $\begin{array}{l}6.84 \times 10^{-3} \\
2.20 \times 10^{-3}\end{array}$ & $\begin{array}{l}1.40 \times 10^{6} \\
2.25 \times 10^{6}\end{array}$ \\
\hline
\end{tabular}

a) See ref. 33 .

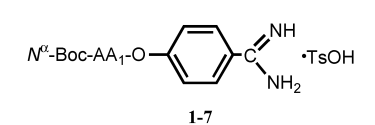

$1-7$

1: $\mathrm{AA}_{1}=\mathrm{Gly} ; 2: \mathrm{AA}_{1}=\mathrm{L}-\mathrm{Ala} ; 3: \mathrm{AA}_{1}=\mathrm{L}$-Leu; 4: $\mathrm{AA}_{1}=\mathrm{L}-$ Phe; 5 : $\mathrm{AA}_{1}=\mathrm{D}-\mathrm{Ala} ; \mathbf{6} ; \mathrm{AA}_{1}=\mathrm{D}-$ Leu; 7: $\mathrm{AA}_{1}=\mathrm{D}-\mathrm{Phe}$

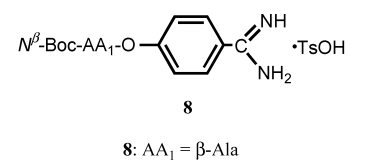

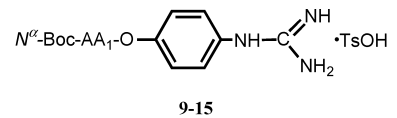

9: $\mathrm{AA}_{1}=$ Gly; 10: $\mathrm{AA}_{1}=\mathrm{L}-\mathrm{Ala} ; 11: \mathrm{AA}_{1}=$ L-Leu; 12: $\mathrm{AA}_{1}=$ L-Phe; 13: $\mathrm{AA}_{1}=\mathrm{D}-\mathrm{Ala} ; 14 ; \mathrm{AA}_{1}=\mathrm{D}$-Leu; 15: $\mathrm{AA}_{1}=\mathrm{D}-\mathrm{Phe}$

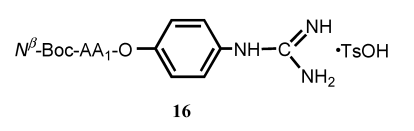

16: $\mathrm{AA}_{1}=\beta-\mathrm{Ala}$
Fig. 1. Structures of Inverse Substrates

erately large for trypsin substrates. All compounds have sufficient affinity and susceptibility to Atlantic cod trypsin. In particular, the observed $k_{2} / K_{s}$ value of $N^{\alpha}$-Boc-D-alanine $p$ amidinophenyl esters was larger than that of $N^{\alpha}$-Boc-L-alanine $p$-amidinophenyl esters. $p$-Guanidinophenyl esters show similar behavior to the trypsin-catalyzed hydrolysis of $p$ amidinophenyl esters as previously described. ${ }^{16)}$ Consequently, two series of inverse substrates were tested against cold-adapted trypsins (chum salmon and Atlantic cod) for trypsin-catalyzed peptide synthesis.

The structures of the inverse substrates $(\mathbf{1}-\mathbf{1 6})$ used in this study are shown in Fig. 1. These inverse substrates were prepared by condensation of the appropriate $N^{\alpha}$-Boc-protected amino acid and $p$ - $\left[N^{\prime}, N^{\prime \prime}\right.$-bis $(Z)$ guanidine $]$ phenol, followed by deprotection by catalytic hydrogenation. ${ }^{16-18)}$ The structures of acyl acceptors ( $\mathbf{a}-\mathbf{c})$ are also shown in Fig. 2.

Because the hydrolysis of reactant components is a serious problem in the enzyme-catalyzed synthetic method, our interest is centered on the temperature dependence of Atlantic cod trypsin-catalyzed hydrolysis of inverse substrates in connection with enzymatic peptide synthesis. We previously investigated the possibility of the nonenzymatic reaction. At $50 \%$ solvent content, $N^{\alpha}$-Boc-L-Ala-OAm (2) underwent some spontaneous hydrolysis with a half-life of about $15 \mathrm{~h}$

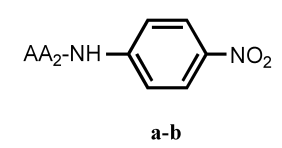

a: $\mathrm{AA}_{2}=\mathrm{L}-\mathrm{Ala} ; \mathrm{b}: \mathrm{AA}_{2}=\mathrm{D}-\mathrm{Ala}$

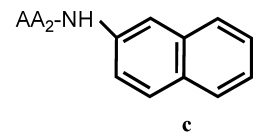

c: $\mathrm{AA}_{2}=\beta-\mathrm{Ala}$
Fig. 2. Structures of Acyl Acceptors

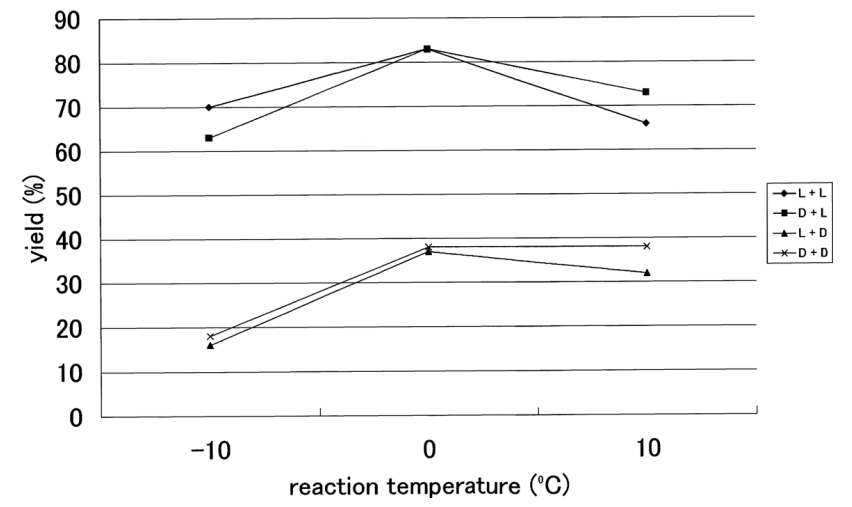

Fig. 3. Atlantic Cod Trypsin-Catalyzed Peptide Synthesis at Various Temperatures of $N^{\alpha}$-Boc-L-Ala-L-Ala- $p$ NA (2a) $(\bullet), N^{\alpha}$-Boc-D-Ala-L-Ala- $p$ NA (5a) (ם), $N^{\alpha}$-Boc-L-Ala-D-Ala- $p$ NA (2b) (A), and $N^{\alpha}$-Boc-D-Ala-D-Ala$p$ NA (2a) $(\times)$

Conditions: acyl donor, $1 \mathrm{~mm}$; acyl acceptor, $20 \mathrm{~mm}$; Atlantic cod trypsin, $5 \mu \mathrm{M} ; 50 \%$ DMSO-GTA ( $50 \mathrm{~mm}, \mathrm{pH} 8.5$, containing $\left.20 \mathrm{mM} \mathrm{CaCl}_{2}\right) ; 0{ }^{\circ} \mathrm{C}$.

and $113 \mathrm{~h}$ at $25^{\circ} \mathrm{C}$ and $0{ }^{\circ} \mathrm{C}$, respectively. ${ }^{23)}$ Analysis of the temperature dependence of Atlantic cod trypsin-catalyzed reactions is in progress. The Atlantic cod trypsin-catalyzed coupling reaction of $N^{\alpha}$-Boc-L-Ala-OAm (2) and $N^{\alpha}$-Boc-DAla-OAm (5) with L-Ala- $p$ NA (a) and D-Ala- $p$ NA (b) to give corresponding $N^{\alpha}$-Boc-Ala-Ala- $p$ NA $(\mathbf{2 a}, \mathbf{5 a}, \mathbf{2 b}, \mathbf{5 b})$ was examined under various reaction temperatures. The highest yield was obtained at $0{ }^{\circ} \mathrm{C}$ in all tested reactions as shown in Fig. 3. Therefore, we were also investigated enzymatic peptide synthesis using another type of inverse substrate, $N$-BocAA-OGu (9-16), which were not previously studied on enzymatic peptide synthesis at low temperature. The other reaction conditions, such as organic solvent, $\mathrm{pH}$, and the acyl acceptor concentration, were used according to the same conditions of chum salmon trypsin. ${ }^{23)}$ Consequently, the standard procedure for the coupling reaction was fixed as follows: acyl donor (inverse substrate), $1 \mathrm{~mm}$; acyl acceptor, $20 \mathrm{~mm}$; Atlantic cod trypsin, $5 \mathrm{~mm}$; 50\% dimethyl sulfoxide (DMSO)GTA (50 mM, pH 8.5, containing $20 \mathrm{~mm} \mathrm{CaCl}_{2}$ ); $0{ }^{\circ} \mathrm{C}$.

The results of the Atlantic cod trypsin-catalyzed coupling reaction were compared with those of the chum salmon trypsin-catalyzed coupling reaction previously reported, $\left.{ }^{23}\right)$ and they are summarized in Table 2. In general, toward all inverse substrates $(\mathbf{1}-\mathbf{1 6})$, both cold-adapted trypsins (Atlantic cod and chum salmon) behaved as a moderately effective catalyst for the synthesis of the peptides (Entries $1-19$ in Table 2). As shown in Table 2, Atlantic cod trypsin can be more utilized for the synthesis of peptides containing Damino acid and $\beta$-amino acid than those of the chum salmon trypsin (Entries 6, 9, 10, 15, 18). Atlantic cod trypsin can be also utilized for the synthesis of some D-amino acid and $\beta$ amino acid peptide (Entries 7, 19).

In conclusion, the utility of Atlantic cod trypsin can be proposed as a catalyst for the synthesis of peptides by the use 
Table 2. Yield of Atlantic Cod Trypsin-Catalyzed Peptide Synthesis ${ }^{a)}$

\begin{tabular}{|c|c|c|c|c|c|c|c|}
\hline \multirow{2}{*}{$\begin{array}{l}\text { Entry } \\
\text { No. } \\
1\end{array}$} & \multirow{2}{*}{$\begin{array}{c}\begin{array}{c}\text { Acyl donor } \\
\text { (No.) }\end{array} \\
N^{\alpha} \text {-Boc-Gly-OAm }(\mathbf{1})\end{array}$} & \multirow{2}{*}{$\begin{array}{l}\text { Acyl acceptor } \\
\text { L-Ala-pNA (a) }\end{array}$} & \multicolumn{2}{|c|}{$\begin{array}{c}\text { Reaction } \\
\text { time }^{b)}(\min )\end{array}$} & \multirow{2}{*}{$\begin{array}{c}\begin{array}{c}\text { Product } \\
(\text { No. })\end{array} \\
N^{\alpha} \text {-Boc-Gly-L-Ala- } p \text { NA (1a) }\end{array}$} & \multicolumn{2}{|c|}{$\begin{array}{c}\text { Yield }^{c)} \\
(\%)\end{array}$} \\
\hline & & & 15 & {$[15]^{d)}$} & & 53 & {$[56]^{d)}$} \\
\hline 2 & $N^{\alpha}$-Boc-L-Ala-OAm (2) & L-Ala- $p$ NA (a) & 30 & {$[30]^{d)}$} & $N^{\alpha}$-Boc-L-Ala-L-Ala- $p$ NA & 83 & {$[82]^{d)}$} \\
\hline 3 & $N^{\alpha}$-Boc-L-Ala-OAm (2) & D-Ala- $p$ NA (b) & 60 & {$[60]^{e)}$} & $N^{\alpha}$-Boc-L-Ala-D-Ala- $p$ NA (2b) & 37 & {$[5]^{e)}$} \\
\hline 4 & $N^{\alpha}$-Boc-L-Leu-OAm (3) & L-Ala- $p$ NA (a) & 30 & {$[45]^{d)}$} & $N^{\alpha}$-Boc-L-Leu-L-Ala- $p$ NA (3a) & 90 & {$[85]^{d)}$} \\
\hline 5 & $N^{\alpha}$-Boc-L-Phe-OAm (4) & L-Ala- $p$ NA (a) & 30 & {$[30]^{d)}$} & $N^{\alpha}$-Boc-L-Phe-L-Ala- $p$ NA (4a) & 73 & {$[85]^{d)}$} \\
\hline 6 & $N^{\alpha}$-Boc-D-Ala-OAm (5) & L-Ala- $p$ NA (a) & 90 & {$[60]^{d)}$} & $N^{\alpha}$-Boc-D-Ala-L-Ala- $p$ NA (5a) & 83 & {$[77]^{d)}$} \\
\hline 7 & $N^{\alpha}$-Boc-D-Ala-OAm (5) & D-Ala- $p$ NA (b) & 180 & {$[180]^{e)}$} & $N^{\alpha}$-Boc-D-Ala-D-Ala- $p$ NA (5b) & 38 & {$[4]^{e)}$} \\
\hline 8 & $N^{\alpha}$-Boc-D-Leu-OAm (6) & L-Ala- $p$ NA (a) & 90 & {$[120]^{d)}$} & $N^{\alpha}$-Boc-D-Leu-L-Ala- $p$ NA (6a) & 87 & {$[90]^{d)}$} \\
\hline 9 & $N^{\alpha}$-Boc-D-Phe-OAm (7) & L-Ala- $p$ NA (a) & 90 & {$[60]^{d)}$} & $N^{\alpha}$-Boc-D-Phe-L-Ala- $p$ NA (7a) & 84 & {$[59]^{d)}$} \\
\hline 10 & $N^{\beta}$-Boc- $\beta$-Ala-OAm (8) & L-Ala- $p$ NA (a) & 60 & {$[90]^{d)}$} & $N^{\beta}$-Boc- $\beta$-Ala-L-Ala- $p$ NA (8a) & 25 & {$[4]^{d)}$} \\
\hline 11 & $N^{\alpha}$-Boc-Gly-OGu (9) & L-Ala- $p$ NA (a) & 20 & {$[20]^{e)}$} & $N^{\alpha}$-Boc-Gly-L-Ala- $p$ NA (1a) & 52 & {$[51]^{e)}$} \\
\hline 12 & $N^{\alpha}$-Boc-L-Ala-OGu (10) & L-Ala- $p$ NA (a) & 45 & {$[30]^{e)}$} & $N^{\alpha}$-Boc-L-Ala-L-Ala- $p$ NA (2a) & 74 & {$[76]^{e)}$} \\
\hline 13 & $N^{\alpha}$-Boc-L-Leu-OGu (11) & L-Ala- $p$ NA (a) & 45 & {$[30]^{e)}$} & $N^{\alpha}$-Boc-L-Leu-L-Ala- $p$ NA (3a) & 84 & {$[77]^{e)}$} \\
\hline 14 & $N^{\alpha}$-Boc-L-Phe-OGu (12) & L-Ala- $p$ NA (a) & 45 & {$[30]^{e)}$} & $N^{\alpha}$-Boc-L-Phe-L-Ala- $p$ NA (4a) & 85 & {$[80]^{e)}$} \\
\hline 15 & $N^{\alpha}$-Boc-D-Ala-OGu (13) & L-Ala- $p$ NA (a) & 90 & {$[90]^{e)}$} & $N^{\alpha}$-Boc-D-Ala-L-Ala- $p$ NA (5a) & 68 & {$[66]^{e)}$} \\
\hline 16 & $N^{\alpha}$-Boc-D-Leu-OGu (14) & L-Ala- $p$ NA (a) & 90 & {$[90]^{e)}$} & $N^{\alpha}$-Boc-D-Leu-L-Ala- $p$ NA (6a) & 69 & {$[63]^{e)}$} \\
\hline 17 & $N^{\alpha}$-Boc-D-Phe-OGu (15) & L-Ala- $p \mathrm{NA}$ (a) & 90 & {$[90]^{e)}$} & $N^{\alpha}$-Boc-D-Phe-L-Ala- $p$ NA (7a) & 65 & {$[66]^{e)}$} \\
\hline 18 & $N^{\beta}$-Boc- $\beta$-Ala-OGu (16) & L-Ala- $p$ NA (a) & 60 & {$[60]^{e)}$} & $N^{\beta}$-Boc- $\beta$-Ala-L-Ala- $p$ NA (8a) & 66 & {$[37]^{e)}$} \\
\hline 19 & $N^{\beta}$-Boc- $\beta$-Ala-OGu (16) & $\beta$-Ala- $\beta$-NA (c) & 300 & {$[300]^{e)}$} & $N^{\beta}$-Boc- $\beta$-Ala- $\beta$-Ala- $\beta$-NA (9c) & 45 & {$[26]^{e)}$} \\
\hline
\end{tabular}

a) Conditions: acyl donor, $1 \mathrm{~mm}$; acyl acceptor, $20 \mathrm{~mm}$; Atlantic cod trypsin, $5 \mu \mathrm{m} ; 50 \%$ DMSO-GTA $(50 \mathrm{~mm}, \mathrm{pH} 8.5$, containing $20 \mathrm{~mm}$ CaCl 2$) ; 0{ }^{\circ} \mathrm{C}$. b) The values in brackets are reaction times (min) of chum salmon trypsin-catalyzed peptide synthesis. c) The values in brackets are yields (\%) of chum salmon trypsin-catalyed peptide synthesis. d) See ref. 23. e) This work.

of two series of inverse substrates. The utility of chum salmon trypsin can also be proposed as a catalyst for the synthesis of peptide by the use of $p$-guanidinophenyl esters. This method, which is operative at low temperature, is advantageous since the spontaneous hydrolysis of the acyl donor is retarded as previously described. ${ }^{18,23}$ It must be emphasized that a longer incubation period did not decrease the coupling yields in the present method. This result suggested that secondary hydrolysis of the resulting products by enzyme is negligible.

\section{Experimental}

HPLC analysis was performed by using a reversed column (Shim-pack, CLC-ODS (M), $4.6 \times 250 \mathrm{~mm}$ ) on a Shimadzu LC-10AD pump system equipped with a Shimadzu SPD-10A UV-VIS spectrophotometric detector. ${ }^{1} \mathrm{H}-\mathrm{NMR}$ spectra were recorded on a JEOL ECA-500 spectrometer. Kinetic parameters were determined with a Union Giken RA-410 stopped-flow spectrometer. All inverse substrates, $N$-(tert-butyloxycarbonyl)amino acid $p$ amidino-( $N$-Boc-AA $\left.A_{1}-\mathrm{OAm}\right)$ and $N$-(tert-butyloxycarbonyl)amino acid $p$ guanidinophenyl ester ( $N$-Boc-AA $-\mathrm{OGu})$, were prepared according to our previous papers. ${ }^{16-18)}$ L-Alanine- $p$-nitroanilide (L-Ala- $p$ NA) was purchased from Peptide Institute, Inc. D-Alanine- $p$-nitroanilide (D-Ala- $p N A$ ) was prepared following the reported procedure. ${ }^{35-37)} \beta$-Alanine- $\beta$-naphthylamide hydrobromide ( $\beta$-Ala- $\beta$-NA $\cdot \mathrm{HBr}$ ) was purchased from Bachem. Atlantic cod trypsin [EC 3.4.21.4] (lyophilized) (Lot 24H7150) was purchased from Sigma Chemical Co. HPLC grade DMSO from Kanto Chemical Co., Inc. was used. 3,3-Dimethylglutaric acid and 2-amino-2-methyl-1,3-propanediol, and tris(hydroxymethyl)aminomethane were obtained from Tokyo Chemical Industry Co., Ltd. and ICN Biomedicals, Inc., respectively. $p$-Methylumbelliferyl $p^{\prime}$-guanidinobenzoate was purchased from Merk and Co., Inc.

$N^{\beta}$-(tert-Butyloxycarbonyl)- $\beta$-alanyl- $\beta$-alanine $\beta$-Naphthylamide $(8 \mathrm{c})$ A solution of $N^{\beta}$-Boc-Ala-OH ( $\left.189 \mathrm{mg}, 1 \mathrm{mmol}\right), \beta$-alanine- $\beta$-naphthylamide hydrochloride $(250 \mathrm{mg}, 1 \mathrm{mmol}), N, N$-diisopropylethylamine (129 $\mathrm{mg}, 1 \mathrm{mmol})$ and 1-hydroxybenzotriazole $(135 \mathrm{mg}, 1 \mathrm{mmol})$ in $N, N$-dimethylformamide (DMF) $(1 \mathrm{ml})$ was treated with dicyclohexylcarbodiimide (DCC) $(226 \mathrm{mg}, 1.1 \mathrm{mmol})$ at $0{ }^{\circ} \mathrm{C}$. The reaction mixture was stirred for $1 \mathrm{~h}$ at the same temperature, then warmed to room temperature, and stirring was continued for $20 \mathrm{~h}$. The resulting precipitate of DCUrea was filtered off, and the filtrate was evaporated to dryness in vacuo. The residue was diluted with benzene-AcOEt $(1: 5)$ and purified on a silica gel column. The pure compound $8 \mathbf{c}$ was obtained by recrystallization from AcOEt (77.3\%). Colorless needles. mp $177-177.5^{\circ} \mathrm{C} .{ }^{1} \mathrm{H}-\mathrm{NMR}\left(\mathrm{CDCl}_{3}\right) \delta: 1.41(9 \mathrm{H}, \mathrm{s}), 2.37(2 \mathrm{H}, \mathrm{d}$, $J=5.7 \mathrm{~Hz}), 2.65(2 \mathrm{H}, \mathrm{d}, J=5.7 \mathrm{~Hz}), 3.39(2 \mathrm{H}, \mathrm{m}), 3.64(2 \mathrm{H}, \mathrm{m}), 5.07(1 \mathrm{H}$, brs), $6.39(1 \mathrm{H}, \mathrm{brs}), 7.39-7.47(4 \mathrm{H}, \mathrm{m}), 7.75-7.76(2 \mathrm{H}, \mathrm{m}), 8.11(1 \mathrm{H}$, br s), $8.23(1 \mathrm{H}, \mathrm{s})$. Anal. Calcd for $\mathrm{C}_{21} \mathrm{H}_{27} \mathrm{~N}_{3} \mathrm{O}_{4}$ : C, 65.44; H, 7.06; N, 10.90 . Found: C, 64.78; H, 7.20; N, 10.78. HR-MS m/z: 408.1898 (Calcd for $\left.\mathrm{C}_{21} \mathrm{H}_{27} \mathrm{~N}_{3} \mathrm{O}_{4} \mathrm{Na}: 408.1899\right)$.

Kinetic Parameters for Atlantic Cod Trypsin-Catalyzed Hydrolysis Active titration revealed that the concentration of Atlantic cod trypsin was $55 \%$ using $p$-methylumbelliferyl $p^{\prime}$-guanidinobenzoate according to the literature. ${ }^{38)}$ The kinetic parameters, $K_{s}, k_{2}$ and $k_{3}$ for Atlantic cod trypsin-catalyzed hydrolysis, were determined by means of the thionine displacement method using a stopped-flow technique. ${ }^{15,34)}$ The reaction was carried out in $0.05 \mathrm{M}$ Tris- $\mathrm{HCl}$ buffer, $\mathrm{pH} 8.0$, containing $0.02 \mathrm{M} \mathrm{CaCl}_{2}$ at $25^{\circ} \mathrm{C}$. In these experiments, the concentrations were: enzyme, $3.31 \times 10^{-6}-7.83 \times 10^{-6} \mathrm{M}$; substrate, $2.40 \times 10^{-5}-1.01 \times 10^{-3} \mathrm{M}$; thionine; $2.50 \times 10^{-5} \mathrm{M}$, respectively.

Enzymatic Peptide Coupling Reaction The peptide coupling reaction was carried out at $0{ }^{\circ} \mathrm{C}$ in $50 \%$ DMSO solution, which was mixed with $50 \mathrm{~mm}$ solution of 3,3-dimethylglutaric acid (G), tris(hydroxymethyl)aminomethane (T), and 2-amino-2-methyl-1,3-propanediol (A) (GTA buffer) ( $\mathrm{pH}$ 8.5 , containing $20 \mathrm{~mm} \mathrm{CaCl}_{2}$ ). The concentrations of acyl donors (1-16), acyl acceptors $(\mathbf{a}-\mathbf{c})$, and enzymes were $1 \mathrm{~mm}, 20 \mathrm{~mm}$, and $5 \mathrm{~mm}$, respectively. The progress of the peptide coupling reaction was monitored by HPLC under the following conditions: isocratic elution at $1 \mathrm{ml} / \mathrm{min}, 0.1 \%$ trifluoroacetic acid/acetonitrile. An aliquot of the reaction mixture was injected, and the eluate was monitored at $310 \mathrm{~nm}$ (chromophore due to $p$-nitroanilide moiety) and $240 \mathrm{~nm}$ (chromophore due to $\beta$-naphthylamido moiety). Peak identification was made by correlating the retention time with that of an authentic sample that was chemically synthesized. ${ }^{39-41)}$ The observed peak areas were used to estimate sample concentration. In Fig. 3, yield of the same product was same reaction time in each reaction temperature.

Acknowledgments This work was supported in part by a Grant-in-Aid for High Technology Research Programs and Strategic Projects to Support the Formation of Research Bases at Private Universities from the Ministry of Education, Culture, Sports, Science and Technology of Japan, and by a grant from the Japan Private School Promotion Foundation.

\section{References}

1) Nishimura T., Kato H., Food Rev. Int., 4, 175-194 (1988).

2) Tsuzuki H., Oka T., Morihara K., J. Biochem. (Tokyo), 88, 669-675 (1980).

3) Nakatuka T., Sasaki T., Kaiser T. E., J. Am. Chem. Soc., 99, 44854488 (1987).

4) Wong C.-H., Science, 244, 1145-1152 (1989).

5) Schellenberger V., Jakubke H.-D., Angew. Chem. Int. Ed. Engl., 30, 1437-1449 (1991)

6) Gill I., Fandio R. L., Jobra X., Vulfson E. N., Enzyme Microb. 
Technol., 18, 162-183 (1996).

7) Bordusa F., Chem. Rev., 102, 4817-4867 (2002).

8) Kumar D., Bhalla T. C., Appl. Microbiol. Biotecnol., 68, 726-736 (2005).

9) Widmer F., Breddam K., Johansen J. T., Carlsberg Res. Commun., 46, 97-106 (1981).

10) Cerovsky V., Jakubke H.-D., Int. J. Peptide Protein Res., 44, 466- 471 (1994).

11) Scuster M., Munoz B., Yuan W., Wong C.-H., Tetrahedron Lett., 34, $1247-1250$ (1993).

12) Schuster M., Wang P., Paulson J. C., Wong C.-H., J. Am. Chem. Soc., 116, 1135-1136 (1994).

13) Wong C.-H., Schuster M., Wang P., Sears P., J. Am. Chem. Soc., 115, 5893-5901 (1993).

14) Tanizawa K., Kasaba Y., Kanaoka Y., J. Am. Chem. Soc., 99, 44854488 (1977).

15) Nozawa M., Tanizawa K., Kanaoka Y., J. Pharmacobio-Dyn., 3, 213 219 (1980).

16) Itoh K., Sekizaki H., Toyota E., Tanizawa K., Chem. Pharm. Bull., 43, 2082-2087 (1995).

17) Sekizaki H., Itoh K., Toyota E., Tanizawa K., Chem. Pharm. Bull., 44, 1577-1579 (1996).

18) Itoh K., Sekizaki H., Toyota E., Fujiwara N., Tanizawa K., Bioorg. Chem., 24, 59-68 (1996).

19) Sekizaki H., Itoh K., Toyota E., Tanizawa K., Chem. Pharm. Bull., 44, 1585-1587 (1996).

20) Sekizaki H., Itoh K., Toyota E., Tanizawa K., Tetrahedron Lett., 38, 1777-1780 (1997).

21) Sekizaki H., Itoh K., Toyota E., Tanizawa K., Chem. Pharm. Bull., 46 846-849 (1998).

22) Sekizaki H., Itoh K., Toyota E., Tanizawa K., Chem. Pharm. Bull., 47, 104-110 (1999).

23) Sekizaki H., Murakami M., Itoh K., Toyota E., Tanizawa K., J. Mol. Catal. B: Enzym., 11, 23-28 (2000).
24) Sekizaki H., Itoh K., Toyota E., Tanizawa K., Amino Acids, 21, 175 184 (2001).

25) Vecchi S. D., Coppers Z., J. Food Biochem., 20, 193-214 (1996).

26) Simpson B. K., Haard N. F., Can. J. Biochem. Cell Biol., 62, 894-900 (1984).

27) Osnes K. Kr., Mohr V., Comp. Biochem. Physiol., 82B, 607-619 (1985).

28) Asgeirsson B., Fox J. W., Bjarnason J. B., Eur. J. Biochem., 180, 8594 (1989).

29) Gildberg A., Overbo K., Comp. Biochem. Physiol., 97B, 775-782 (1990).

30) Asgeirsson B., Bjarnason J. B., Comp. Biochem. Physiol., 99B, 327335 (1991).

31) Kristjansson M. M., Nielsen H. H., Comp. Biochem. Physiol., 101B, 247-253 (1992).

32) Asgeirsson B., Bjarnason J. B., Biochem. Biophys. Acta, 1164, 91100 (1993).

33) Sekizaki H., Itoh K., Murakami M., Toyota E., Tanizawa K., Comp. Biochem. Physiol., 127B, 337-346 (2000).

34) Brot E. F., Bender M. L., J. Am. Chem. Soc., 91, 7187-7191 (1969).

35) Oyamada H., Saito T., Inaba S., Ueki M., Bull. Chem. Soc. Jpn., 64, 1422-1424 (1991).

36) Kasafirek E., Fric P., Slaby J., Malis F., Eur. J. Biochem., 69, 1-13 (1976).

37) Tuppy H., Wiesbauer U., Wintersberger E., Hoppe-Seylers Z., Physiol. Chem., 329, 278-288 (1962).

38) Colemen P. L., Latham H. G., Show E. N. Jr., "Methods in Enzymology," Vol. 45, ed. by Colowick S. P., Kaplan N. O., Academic Press, New York, 1976, pp. 12-26.

39) Kawai M., NagaiI U., Bull. Chem. Soc. Jpn., 55, 1327-1328 (1982).

40) Okada Y., Tsuda Y., Hirata A., Nagamatsu Y., Okamoto U., Chem. Pharm. Bull., 30, 4060-4068 (1982).

41) Bieth J., Weremath C. G., Biochem. Biophys. Res. Commun., 53, $383-390$ (1970). 